| Research Article / Araştırma Makalesi|

\title{
Can Dialogic Discourse Enhance Student Active Participation?
}

\section{Diyalojik Söylem Öğrencinin Derse Aktif Katımını Arttırabilir mi? ${ }^{1}$}

\section{YıImaz SAĞLAM ${ }^{2}$, Sedat KANADLI ${ }^{3}$, Pınar GÖKSU ${ }^{4}$, Emine Aynur GizLENCi ${ }^{5}$, Vildan KARATEPE ${ }^{6}$}

\author{
Keywords \\ 1. Dialogic discourse \\ 2. Authoritative \\ discourse \\ 3. Active participation

\section{Anahtar Kelimeler} \\ 1. Diyalojik söylem \\ 2. Otoriter söylem \\ 3. Aktif katılım
}

\section{Received/Başvuru Tarihi}

09.06.2020

Accepted / Kabul Tarihi

06.12.2020

\begin{abstract}
Purpose: This study aimed to investigate contribution of a professional development program committed to providing quality training to support dialogic talk to student active participation. Indicators of active participation, in the context of this study, were the speaking duration of the teacher compared to student, the number of different ideas of the students emerging in the classroom milieu, the number of students answering per question asked by the teacher, and the rate of students' personal answers for the questions asked by the teacher.
\end{abstract}

Design/Methodology/Approach: In recruiting teachers, gathering, and analyzing data, the educational design-based research (DBR) method was adopted. A total of seventeen teachers volunteered and participated in a four-week course program. The program involved theoretical and practical information about authoritative and dialogic talk. After the program had been completed, the teachers worked in pairs, designed lesson plans, and implemented the plans in their classrooms. Teachers' preand post-intervention practices were videotaped and then transcribed.

Findings: A total of four teachers being able to successfully implement the dialogical discourse in their classrooms were selected for analysis and the findings are reported in the present study. The descriptive analysis showed that dialogical discourse generally contributed a significant increase in student talk ratio, number of student responses, new ideas, and students' personal responses.

Highlights: Dialogical discourse-based education has reduced the speaking time of teachers. It contributed to the emergence of different ideas in the classroom. It increased students' active participation in the lesson and their individual response rates. Öz

Çalışmanın amacı: Bu çalışmanın amacı diyalojik söylemi geliştirmeye yönelik olarak tasarlanan bir hizmet içi eğitim programının sınıf içi öğrenci aktif katııımına olan katkısını araştırmaktır. Bu çalışma bağlamında sınıf-içi aktif katılım; öğretmenin öğrenciye göre konuşma süresi, sınıfta ortaya çıkan öğrenci farkı fikir sayısı, öğretmen tarafından sorulan bir soru başına cevap veren öğrenci sayısı ve öğretmen tarafından sorulan soruların öğrenci tarafından bireysel olarak yanıtlanma oranı olarak belirlenmiş̧ir.

Materyal ve Yöntem: Araştırmada öğretmen seçimi, verilerin toplanması ve analiz edilmesinde, tasarım tabanlı araştırma (DBR) metodu benimsenmiştir. Çalışmada toplamda on yedi öğretmen gönüllü olarak dört haftalık bir eğitim programına katılmıştır. Program, diyalojik ve otoriter söylemler ile ilgili teorik bilgiler ve bu söylemlerin uygulama örneklerinden oluşmuştur. Programın sonunda öğretmenler partnerleri ile birlikte çalışarak ders planları tasarlamışlar ve kendi sınıflarında bu planları uygulamışlardır. Tüm uygulamaların (eğitim öncesi ve sonrası sınıf içi uygulamaların) video kayıtları yapılmış ve bu kayıtlar akabinde yazılı hale getirilmiştir.

Bulgular: Bu çalışmada diyalojik söylemi sınıflarında en iyi kullanan dört öğretmenin sınıf uygulamaları analiz edilmiştir. Araştırma verilerinin betimsel analizleri diyalojik söylemin, öğrencilerin konuşma süresinde, derse katılma oranlarında, yeni fikirler ortaya koymalarında ve öğrencilerin bireysel yanıtlama oranında genel olarak anlamlı bir artışa katkı sağladığı belirlenmiştir.

Önemli Vurgular: Diyalojik söylem temelli eğitim öğretmenlerin konuşma sürelerini düşürmüştür. Sınıfta farklı fikirlerin ortaya çıkmasına katkı sağlamışıı. Öğrencilerin derse aktif katıımını ve bireysel cevap verme oranlarını arttırmıştır.

\footnotetext{
${ }^{1}$ The study was supported by TUBITAK (Scientific and Technological Research Council of Turkey) (Project \#: 113K693).

${ }^{2}$ Kilis 7 Aralık Üniversitesi, Muallim Rıfat Eğitim Fakültesi, Temel Eğitim Bölümü, Kilis, TÜRKiYE; https://orcid.org/0000-0002-5076-8339.

${ }^{3}$ Mersin Üniversitesi, Eğitim Fakültesi, Eğitim Bilimleri, Mersin, TÜRKiYE; https://orcid.org/ 0000-0002-0905-8677.

${ }^{4}$ Milli Eğitim Bakanlı̆̆ı, Adıyaman, TÜRKIYE; https://orcid.org/ 0000-0001-7882-0971.

${ }^{5}$ Milli Eğitim Bakanlı̆̆ı, Gaziantep, TÜRKiYE; https://orcid.org/ 0000-0001-5486-2894.

${ }^{6}$ Syracuse Üniversitesi Doktora Öğrencisi, Newyork, AMERIKA; https://orcid.org/0000-0001-9379-533X
} 


\section{INTRODUCTION}

Meaning first emerges from the child-adult interaction on a social plane and then finds a psychological ground for itself (Vygotsky, 1978). In other words, external speech, which grows on a social basis, then turns into internal speech in the individual and becomes a thinking (cognitive) tool that the individual could use in the face of a problem (Vygotsky, 1930). Therefore, the origins of the cognitive development should be sought in one's social interactions. Similarly, student-teacher interactions in the classroom can shape the way students think. The discourse used by the teacher has the feature of influencing students' critical thinking skills (Hajhosseiny, 2012), problem-solving skills, and reasoning (Gillies \& Khan, 2009). In addition, teacher discourse can also affect students' internalization of concepts, in other words, their appropriation of concepts (Billett, 1998).

If the meaning is socially created as a result of teacher-student and student-student interaction in the classroom environment, this type of interaction is called dialogic discourse. An instruction based on dialogic discourse improves students' scientific reasoning and understanding in science classrooms (Mercer et.al., 1999; Mercer et.al., 2004) and has the potential to increase their motivation towards the subject matter (Mercer et.al., 2009; Scott, 2008), may contribute to the development of arguments (Demirbağ, 2017), and may improve critical thinking skills (Hajhosseiny, 2012); however, the research on the impact of dialogic discourse on student participation seems inadequate. Therefore, in this study, a professional development program was developed to train several teachers. The aim of this study is to find out the impact of this professional development program on the students' active participation in the classroom.

Active participation can be defined as a process in which the student himself/herself constructs his/her own knowledge by interacting with the learning environment designed by the teacher. This process occurs as a result of teacher's deliberate and conscious attempt to encouraging active participation in the classroom milieu (Pratton \& Hales, 1986). Therefore, the discourse that the teacher uses in the classroom consciously or unintentionally has the power to affect the active participation of the students in the class. In the context of this study, the signals of active participation in the classroom were the speaking duration of the teacher compared to students, the number of different ideas of the students emerging in the classroom milieu, the number of students' answers per question, and the rate of students' personal answers for the questions.

Teachers generally use two types of discourse language in the classroom, authoritative and dialogic (Mortimer \& Scott, 2003). Authoritarian discourse is more teacher-centered and is a form of discourse in which students are seen as objects. In this discourse, only the voice of authority is heard and what is said is not open to discussion (Bakhtin, 1981). In this type of communication, student ideas are unimportant and not allowed to be discussed in class; rather, it is desired by the teacher that students focus on the scientific point of view (Mortimer, 2005). In this discourse, if the ideas suggested by the student contribute to the scientific point of view, the teacher considers these ideas, while if they do not, he ignores these ideas (Scott et.al., 2006). In authoritarian discourse, the teacher is expected to control student ideas, rearrange them and present the scientific point of view, while the student is expected to follow the directions from the teacher and accept the scientific point of view (Scott et.al., 2006).

Unlike authoritarian discourse, dialogic discourse is more student-centered and in this discourse, the student is seen as a subject. For this reason, in dialogic discourse, the unique voices of individuals are heard and what is said is open to discussion (Bakhtin, 1981). The main feature of dialogic discourse is that it allows the discovery of student ideas and the development of new ideas by discussing these discovered ideas (Mortimer, 2005). Thus, in this discourse, the teacher considers more than one point of view, reveals different ideas, and interprets these ideas and relates them to the scientific point of view (Mortimer \& Scott, 2003, p.33). While the teacher is expected to explore students' ideas and compare different perspectives in dialogic discourse, students are asked to share their ideas, listen to others, try to understand the ideas put forward, and gain new ideas by discussing with others (Scott et.al., 2006).

Another difference between authoritarian and dialogic discourses is that authoritarian discourse does not have a specific time and place, whereas dialogic discourse emerges in a specific time and place (McCormick \& Donato, 1998). Let us now examine the dialogic and authoritative types of discourses through two examples. The following dialogues are taken from a science class. In this class, a dialogue about plant roots takes place between the teacher and the students. In this and the following dialogue, the letter $T$ stands for the teacher and pseudonyms were used for the students.

$01 \mathrm{~T}$ : Guys, we have seen many plants around us and you may have noticed that the roots of these plants are different from each other [Teacher projects a picture of 3 different types of roots on the board]. How many types of plant roots do you think there are? and what are the properties of these roots? Who can tell me?

Ahmet!

02 Ahmet: Teacher, there are 3 types of roots. These are tap, fibrous and storage roots.

03 T: Good! Right, well done. So who's going to say what they're about? Semih!

04 Semih: Teacher, fibrous roots connect the plant to the deep.

$05 \mathrm{~T}$ : Is that so? Did your friend tell the truth? What was the feature of the fibrous root? Ahmet!

06 Ahmet: Teacher, in fibrous roots, the main root and the lateral roots are the same in terms of thickness. Teacher, these roots occupy a large area near the surface of the soil.

08 T: Good, Fatima!

09 Fatma: In the tap root, the main root is thick, while the lateral roots are thin and attached to the main root. $10 \mathrm{~T}$ : Well done! Beautiful. You are telling the truth. So who's to say storage root?

| Kastamonu Education Journal, 2022, Vol. 30, No. 1 | 
11 Fatih: The plant stores nutrients in the root.

In this dialogue, the teacher used an authoritarian discourse. In this type of discourse, only one voice is heard, and this voice is the voice of the superiors. In the above dialogue, it can be thought that there are four students' (Ahmet, Semih, Fatma, and Fatih) voices and the teacher's voice. But in reality, only one voice is heard in the above dialogue, and that voice is the scientific voice. Notice that there are 3 types of roots ( $2^{\text {nd }}$ statement), tap, fibrous and storage roots ( $2^{\text {nd }}$ statement), the main root and lateral roots are the same in terms of their thickness $\left(6^{\text {th }}\right.$ statement), while the main root is thick in tap root, the lateral roots are thin (9th statement) are scientific and they voice scientific facts. While the teacher accepts the correct (scientifically accepted) ideas $(2,6,9,11)$ he rejects the inappropriate idea $(4)$. Therefore, only one voice is heard in this dialogue, and this voice is the voice of science. This voice is an alien one for other students in the class who are unfamiliar with this discourse (for students who do not know the subject). This type of speech belonging to the superiors (scientists), is incomprehensible, indisputable, and inaccessible. Secondly, there is no time and space in this discourse. The above-mentioned terms such as tap root, hairy root, storage root, main root, and lateral root can be used today, have been used in the past and have the potential to be used in the future. Time and space cannot limit this type of discourse. Now let's examine a dialogue in which dialogic discourse exists on the same subject.

$01 \mathrm{~T}$ : [The teacher brings corn, beans, and potatoes to the class with soil in it. At the same time, he projects a picture on the board where these three plants are shown in the soil. He forms groups of three or four of the students]. "Guys, these are the roots of corn, beans, and potatoes. Look, they're still on their land. I want you to work as a group and draw these roots in your notebooks." [Students try to draw pictures of roots in their notebooks. The teacher walks between the groups]. "I think everyone drew it. Is there any group that didn't draw? [No response from the class]. "Okay, then who will tell me the differences between these roots? Yes",

02 Group 3: Corn root is more scattered than the others. More. Hard.

$03 \mathrm{~T}$ : Good! Another! [Teacher notes student's statements on the board]

04 Group 5: Teacher, we can eat the potato, but the corn and bean root are inedible. Others are tough.

$05 \mathrm{~T}$ : Good! What else? [Teacher notes student's statements on the board]

06 Group 2: Bean root long and branched. More delicate. Potatoes are fat. Corn root is scattered and numerous.

$08 \mathrm{~T}$ : Good! Yes, you are. [Teacher notes student's statements on the board]

09 Group 1: One long vein in the bean root and the small veins connected to this vein, in corn all the veins are elongated from the main stem, in potatoes there is no veining. ...

17 T: Well, done! Beautiful. [Teacher notes student's statements on the board] Now, friends, you all found the differences very nice. This is how (showing the bean root) there is a long root in the middle and short roots attached to this root in biology, tap root in biology, if it is messy like you said (pointing to the corn root) fibrous root and this way (pointing to the potato) you call it. If it can be eaten like a nutrient, that is, if it stores nutrients, such roots are also called storage roots. [Teacher notes Tap Root, Fibrous Root, and Storage Root on the board]

In this dialogue, the teacher used a dialogic discourse. In this sort of discourse, multiple voices are heard, the voices are unique (belonging to individuals) and are intelligible. In the dialogue above, the group's first drew the plant roots and then expressed the differences between them. However, in this way of expression, unlike the previous dialogue, we hear more than one voice and witness the students' own thoughts. "We can eat the potato, but the corn and the bean root are inedible" (4 ${ }^{\text {th }}$ statement), "The bean root is long and branched. More delicate. The potato is fat" (6th statement), "One long vein in the bean root and small veins attached to this vein" $\left(9^{\text {th }}\right.$ statement). When the statements are examined, it is seen that these discourses are original ideas belonging to the students. These statements are not scientific and can be easily recognized by other students. Secondly, there is time and space in this discourse. All the conversations above between teacher and students are about the three roots that are brought into the classroom. So all conversations that occur have a time and a space. The corn root spoken about is the corn plant that is currently in class, or the bean root spoken about is related to the bean plant that is in the current class.

\section{Purpose of the study}

The aim of this study is to determine the contribution of a professional development program designed to develop dialogic discourse to the active participation of students in the classroom. For this purpose, answers to the following research questions were sought:

1. How does dialogic discourse-based instruction contribute to teachers' in-class speaking time?

2. How does dialogic discourse-based instruction contribute to the number of new ideas?

3. How does dialogic discourse-based instruction contribute to the number of students attending the course?

4. How does dialogic discourse-based instruction contribute to students' individual response rates? 


\section{METHOD}

This study is a design-based research. Design-based research is a research method that provides validity to the research by being carried out in realistic educational environments and the results obtained contribute to the evaluation, regulation and development of applications in these contexts (Anderson \& Shattuck, 2012). Design-based research, like experimental studies, has an intrusive feature; however, unlike experimental studies, the intervention can be changed and improved as the process continues (Bakker \& van Eeerde, 2015). In the context of this study, the videos of the classroom teachers were taken before the intervention started, feedbacks and corrections were made on the work they did in the classroom while the intervention continued, and at the end of the intervention, the videos were shot again and compared with the preliminary videos. The type of discourse used by teachers in their classroom practices was published in another qualitative study (Saglam, et al. 2015). In this study, the contribution of the professional development program to the active participation of students in the classroom is reported.

\section{Teacher Selection and Pre-Training Video Shooting}

Criterion sampling method, one of the purposive sampling methods, was used to determine the study group. In this method, individuals who meet a set of predetermined criteria are included in the sample (Yıldırım \& Şimşek, 2006, p.112). In the context of this study, the criteria were determined as (i) teachers being classroom teachers, (ii) teaching second or third grades, (iii) being able to attend at least two people from the same school, and (iv) volunteering. A total of 21 classroom teachers voluntarily participated in the professional development program prepared accordingly. These teachers work in public schools and were chosen from among the teachers who actually took the course and wanted to take part in the project voluntarily. Since data will be collected for at least two semesters during the research and teachers must stay in their current classrooms during this period, 2nd and 3rd grade teachers were preferred in the selection of the candidates. In addition, teachers were planned to work together during and after the training, and during the application, teachers were asked to apply from the same school in pairs or groups of three. Therefore, individual applications were not accepted. The research consists of two stages. In the first stage of the study, a total of 17 teachers ( 7 groups in pairs and 1 group in three) participated in the trainings, and their in-class dialogues were followed throughout the program. The video-recordings of these teachers were analyzed in terms of dialogic and authoritative discourse (Appendix-1), and as a result of these analyzes, four teachers who were able to successfully apply dialogic discourse in their classrooms and had the highest level of development (T3, T4, T11 and T15) were selected to participate in the second phase of the study. In this study, the practices of these four teachers are reported.

\section{Data Collection Method}

Data were collected through in-class video footage. Before the trainings, permissions were obtained from the students and parents for video shooting, and the teachers' in-class practices were recorded with a video recorder. A total of 90 videos (5 videos for each teacher on average) of mathematics, science and social studies lessons were shot. The trainings started in April 2014 and were completed at the end of 4 sessions (5, 13, 18 and 25 April 2014). Each training took approximately 3 hours. During the trainings, information was given about dialogic and authoritative discourse. In this process, besides the theoretical information, examples from classroom practices were also presented. In the selection of the examples, the 2 nd and 3rd grade curriculum was taken into account. At this stage, teachers had the opportunity to watch sample applications of mathematics, science and social studies lessons from these grade levels. In the last week of the training and in the weeks following the training, the teachers were asked to make lesson plans to implement in their own classrooms. In consultation with researchers and working with their partners, teachers planned lessons and implemented them in their classrooms. The classroom practices of the teachers after the training were recorded again with the help of video recorders. A total of 63 videos (4 videos for each teacher on average) of mathematics, science and social studies lessons were shot. This number was more than the planned number (average of 3 videos), which again allowed for a more comprehensive data analysis. In this way, teachers have the opportunity to follow good classroom practices, participate in a training program that spans time and allow mutual discussions, learn a concept directly related to their classroom practices (dialogical discourse), have the opportunity to work with a colleague from the same school and grade level, and actively participate in this process. Discussing, planning and designing courses are among the important features of professional development programs (Wilson \& Berne, 1999; Garet et al., 2001; Desimone, 2009). All the videos captured were then transcribed by the researchers. Among the limitations of this research are the participation of a small number of teachers in the trainings, the completion of the trainings in a period of one month, and the inevitably affecting the classroom practices of the teachers.

\section{Data analysis}

In this study, the video collected data of 4 teachers who participated in the second stage of the professional development program were written down and analyzed on the basis of the table (Appendix-2) given in the appendix. Teachers' pre- and posttraining practices were compared in terms of student speaking time, student participation, number of different ideas and the rate of expressing these ideas individually. For this purpose, a pre-training video and a post-training video were selected for analysis. 
In this selection stage, attention was paid to the selection of videos from the same course type. For example, if a Turkish lesson belonging to the pre-training was selected for analysis, another Turkish lesson was chosen for analysis after the training. Descriptive statistics (frequency and percentages) were used in the analysis of these data.

Chi-square test can be used to determine whether there is a significant difference between observational data in experimental and survey studies (Büyüköztürk, 2005. p.146). In this study, in-class videos of teachers before and after the application; A single sample chi-square test was used to determine whether there was a significant difference between speaking times, the number of different ideas, the number of students attending the course and the individual response rates of the students.

\section{Data Analysis Reliability}

The classroom practices of the teachers were first analyzed by the researchers according to the table given in Appendix 2 . In order to determine the reliability of these analyzes, a randomly selected video and code definition tables were given to three different researchers. Researchers were asked to analyze these videos and transcripts independently of each other based on the criteria given in the table. Researchers analyzed each other's videos in terms of question type, number of respondents (teacher, class, or student), number of ideas and speaking times (teacher and student), and proportions of all these numbers. In these analyzes, it was seen that there was a consensus of over $90 \%$ in terms of the number of codes (types and number of questions) and speaking times. Therefore, this result showed that the coding made had a high level of reliability (Miles \& Huberman, 1994, p.69).

\section{FINDINGS}

The teacher-student dialogues that emerged in the classrooms of successful teachers (T3, T4, T11, T15) before and after the training were analyzed according to the definition table given in Appendix 1, and question types were determined. Afterwards, each transcript and video was analyzed by the scholars according to the table given in Appendix 2. One pre-training video and one post-training video of each teacher were selected for analysis. In this selection stage, attention was paid to the selection of videos from the same course type. For example, if a Turkish lesson belonging to the pre-training was selected for analysis, another Turkish lesson was selected for analysis after the training. In the analysis phase, first of all, the number of question types used by teachers and the number of answers to these questions by the teacher, students or class were determined. Afterwards, these numbers were divided by the total number of questions and their ratios were calculated. For example, 20 of T3's 56 questions in total were answered by the students and 36 by the class before the training. The percentage of answers to the questions by the students was found by dividing 20 by 56 and multiplying the result by $100(36 \%)$. This information can be seen in the first seven columns of the table. After this stage, the number of students who responded was determined. In this determination process, how many students answered each question type was made by looking at the transcripts (counting how many different students answered). The number of students who answered per question was determined by dividing the number of students who answered by the number of questions. For example, in T3's class, 33 students answered 19 questions of the definition type. Therefore, in this example, the number of students per question was calculated by dividing 33 by 19 (1.7). While determining the number of students' claims of different solutions/ideas, the number of answers different from the first answer given to each question was found. For example, in T3's class, a total of 11 different answers (solution, idea or assertion) were received to the definition type questions. While determining the teacher and student speaking times, the videos were watched and the durations of the teacher and student speaking sections were found in these videos. Activities such as extracurricular conversations, moments of silence or reading a book are not included in these speaking times. After the obtained times were divided by the total time, the ratios of teacherstudent speaking times were calculated.

\section{Contribution of Dialogical Discourse-Based Instruction to Teacher Speaking Times}

The percentage of participating teachers' speaking time was calculated over the ratio of teacher speaking time to total student and teacher speaking time. Therefore, a decrease in teacher speaking time indicates an increase in student speaking time. The speaking time percentages of the participating teachers before and after the training are given in Figure 1. 


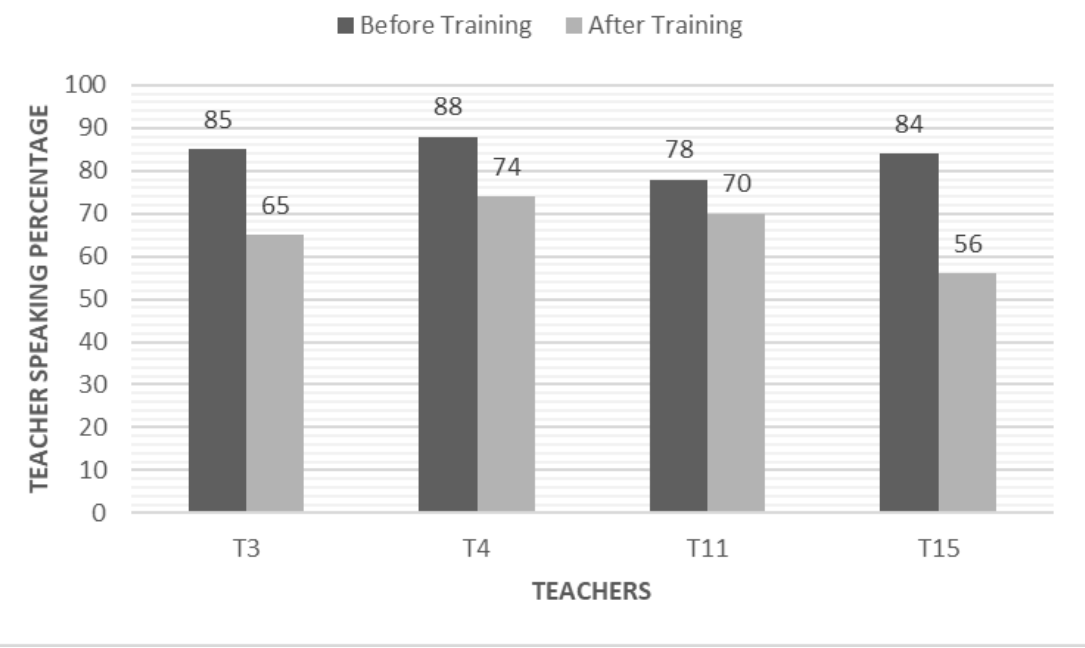

\section{Figure 1. Percentage of teachers speaking time before/after training}

As seen in Figure 1, it was seen that all teachers talked less after the training when compared to the pre-training. According to this, while teachers with the codes Ö3, Ö4, Ö11 and Ö15 spoke at the rate of $85 \%, 88 \%, 78 \%$ and $84 \%$ before the training, this rate decreased to $65 \%, 74 \%, 70 \%$ and $56 \%$, respectively, after the training. The results of the chi-square test performed to determine whether this observed decrease is significant is given in Table 1.

Table 1. Chi-square test result for observation results

\begin{tabular}{lcccc}
\hline Teacher & Before Training & After Training & $\boldsymbol{\chi}^{2}(1)$ & \multicolumn{1}{c}{$\boldsymbol{p}$} \\
\hline T3 & 85 & 65 & 2.667 & .102 \\
T4 & 88 & 74 & 1.210 & .271 \\
T11 & 78 & 70 & 0.432 & .511 \\
T15 & 84 & 56 & 5.600 & $.018^{*}$ \\
\hline
\end{tabular}

$* p<.05$

According to Table 1, only the decrease in the speaking time of the teacher coded T15 was significant $(p<.05)$. Although there was a decrease in the speaking time rate of T3, T4 and T11 coded teachers, this decrease was not significant ( $p>.05)$ at the $95 \%$ confidence level. According to this result, it is seen that dialogic discourse makes a statistically significant contribution to one teacher's class in terms of speaking time.

\section{Contribution of Dialogical Discourse-Based Instruction to the Formation of Different Ideas}

In order to see the contribution of the dialogic discourse to the formation of different ideas before and after the training, the number of different solutions/ideas/claims that emerged in the classroom was compared. Observation results of four teachers are given in Figure 2.

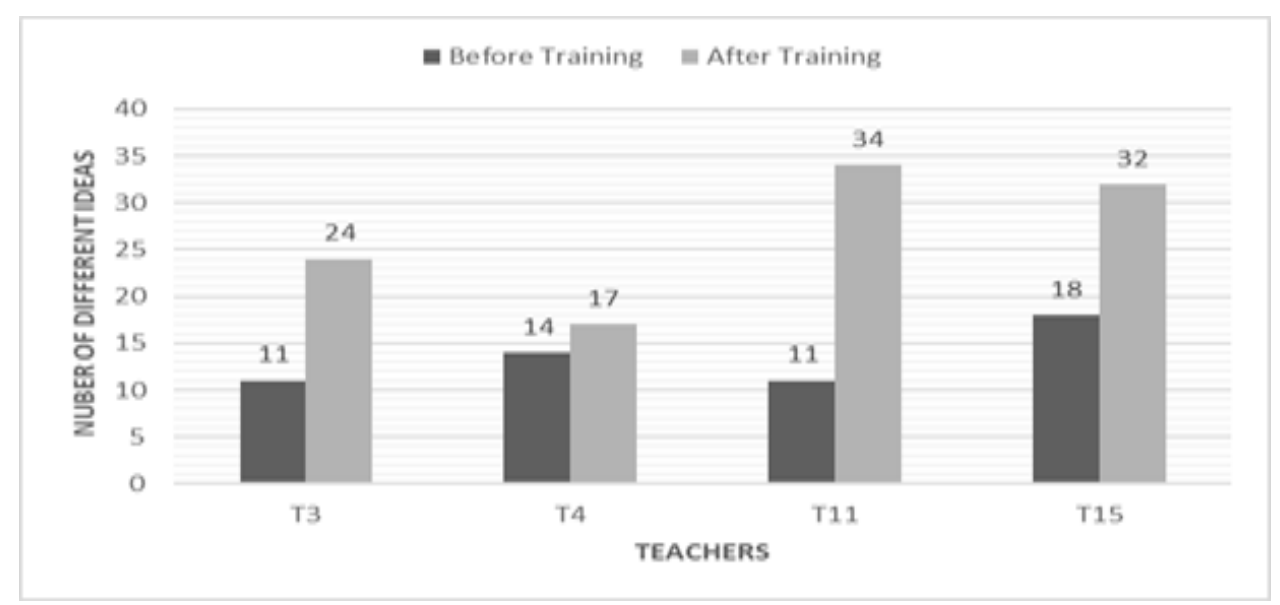

Figure 2. Number of different ideas of students before/after training 
According to Figure 2, in all four classes, the number of students' different ideas increased. While 11, 14, 11, and 18 different ideas emerged, respectively, in the classrooms of T3, T4, T11, and T15 before the training, 24, 17, 34, and 32 different ideas emerged, respectively, after the training. The chi-square test result, which was performed to determine whether there is a significant difference between these observation numbers, is given in Table 2.

Table 2. Chi-square test result for observation results

\begin{tabular}{lccccc}
\hline Teacher & Before Training & After Training & $\boldsymbol{\chi}^{\mathbf{2}(1)}$ & $\boldsymbol{p}$ \\
\hline T3 & 11 & 24 & 4.829 & $.028^{*}$ \\
T4 & 14 & 17 & 0.290 & .590 \\
T11 & 11 & 34 & 11.756 & $.001 * *$ \\
T15 & 18 & 32 & 3.920 & $.048 *$ \\
\hline
\end{tabular}

$* p<.05, * * p<.01$

According to Table 2, while the increase in the number of new ideas emerging in the education classes of T3 and T11 and T15 teachers is significant $(p<.05)$, the increase in the number of T4 teachers is not significant $(p>.05)$. According to this result, it is seen that the dialogic discourse contributes statistically significantly in the classroom of 3 teachers in terms of the emergence of different ideas.

\section{Contribution of Dialogue-Based Instruction to the Number of Students Participating the Class}

The number of students who answered per question in the classrooms of the participating teachers before and after the training was calculated. To calculate this, the total number of students who answered is divided by the total number of questions asked by the teacher. The number of student answers per question observed in the classrooms of the participant teachers before and after the training is given in Figure 3.

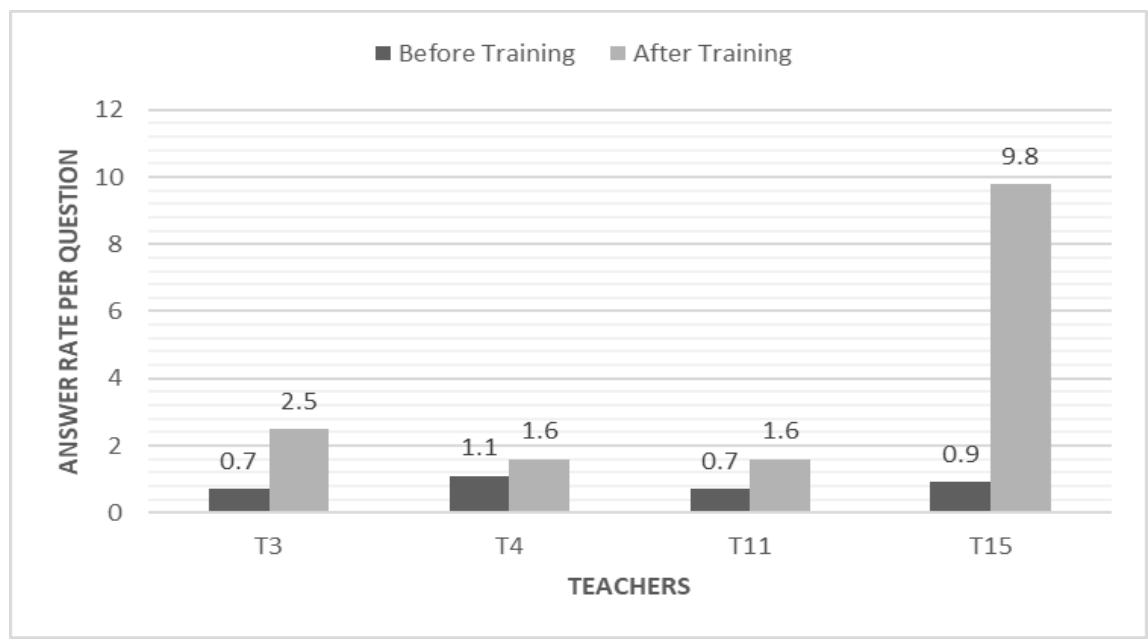

Figure 3. Number of student answers per question asked by the teacher

As seen in Figure 3, in all four classes the number of student answers per question increased. The number of student answers per question was $0.7,1.1,0.7$ and 0.9 , respectively, before the training, and was 2.5, 1.6, 1.6 and 9.8 after the training. The result of the chi-square test performed to determine whether this difference is significant is given in Table 3.

Table 3. Chi-square test result for observation results

\begin{tabular}{lcccc}
\hline Teacher & Before Training & After Training & $\boldsymbol{\chi}^{2}(1)$ & $\boldsymbol{p}$ \\
\hline T3 & 0.7 & 2.5 & 1.000 & .317 \\
T4 & 1.1 & 1.6 & 0.333 & .564 \\
T11 & 0.7 & 1.6 & 0.333 & .564 \\
T15 & 0.9 & 9.8 & 7.364 & $.007^{* *}$ \\
\hline
\end{tabular}

$* p<.05, * * p<.01$ 
As can be seen in Table 3, the number of students who answered per question showed a significant ( $p<.01)$ increase only for the teacher coded T15. Although an increase was observed in other teachers, these increases were not significant at the $95 \%$ confidence level.

\section{Contribution of Dialogue-Based Instruction to Students' Individual Response Rates}

The percentages of individual answers to the questions asked by the students in the classrooms of the participating teachers before and after the training were calculated. These percentages are; the number of individual students' answers to the questions asked by the teachers was determined by dividing the answers given by the teacher, the class and individually by the students. The percentages of students' individual answers to the questions asked by the participant teachers in their classes before and after the training are given in Figure 4.

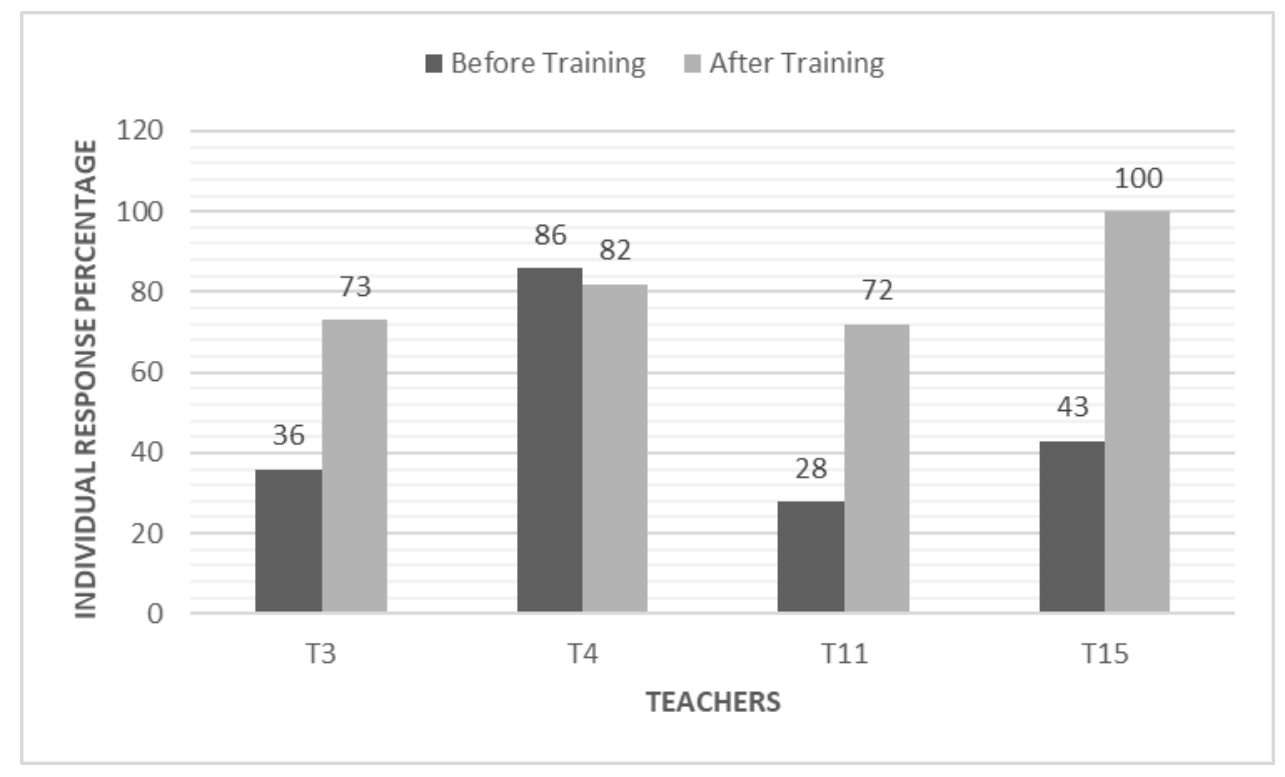

Figure 4. Percentage of students answering the questions individually

As seen in Figure 4, in three classes student individual responses increased. While the percentage of individual answers to the questions in the classrooms of T3, T4, T11 and T15 before the training was 36, 86, 28 and 43, respectively, it was observed as 73, 82,72 and 100, respectively, after the training. Therefore, a participation of over $70 \%$ was achieved by all teachers. There was an increase in 3 of the teachers. The chi-square test result, which was performed to determine whether there is a significant difference between these observation percentages, is given in Table 4.

Table 3. Chi-square test result for observation results

\begin{tabular}{lcccc}
\hline Teacher & Before Training & After Training & \multicolumn{1}{c}{$\boldsymbol{\chi}^{2}(\mathbf{1})$} & 12.560 \\
\hline T3 & 36 & 73 & $.000 * *$ & .095 \\
T4 & 86 & 82 & 19.360 & $.000 * *$ \\
T11 & 28 & 72 & 100 & $.000 * *$ \\
T15 & 43 & 100.720 \\
\hline
\end{tabular}

$* p<.05, * * p<.01$

As can be seen in Table 4, the percentages of individual answers to the questions asked by the teacher by the students showed a significant difference $(p<.01)$ for the teachers coded Ö3, Ö11 and Ö15 after the training, while there was a significant difference $(p>.05)$ for the teacher coded Ö4. did not show. According to this result, it is seen that the dialogic discourse makes a statistically significant contribution in the classroom of 3 teachers in terms of individual response.

\section{DISCUSSION}

In this study, the contribution of the dialogic discourse-based professional development program, which teachers voluntarily participate in, to the active participation of students in the lesson was investigated. Active participation of students in the classroom; the rate of teacher speaking time, the number of different opinions in the class, the number of students answering per question, and the rate of answering the questions individually were examined. For this purpose, a video-recorded lesson of four 
teachers participating in the training before and after the professional development program was compared in terms of indicators of active participation.

As a result of the analysis of the collected data, it was seen that there was a decrease in the speaking time of the teachers compared to the pre-training period. A decrease in teacher speaking time indicates an increase in student speaking time at the same rate; however, this decrease in teacher speaking time showed a significant $(p<.05)$ difference in only one of four teachers. It should not be surprising that different results are obtained in different classes, as the teacher is affected by many external factors such as speaking time, course achievements, subject characteristics, and students' readiness levels. However, according to the TIMSS 1999 report, eighth grade mathematics teachers were found to talk more in class when compared to their own students (Hiebert, et al., 2003, pp.109-110). For example, in the same report, the teacher-student discourse ratio is $16 / 1$ in Hong Kong, 9/1 in Australia, 9/1 in the Czech Republic, and 8/1 in the USA. Considering the teacher-student discourse ratio in this study, it is approximately $2 / 1$ on average. Therefore, it can be said that dialogic discourse contributes to a significant increase in student speaking time compared to the countries mentioned above.

The results also indicated that there was an increase in the students' generating different ideas, the number of students who answered per question, and the individual response rates compared to the pre-training period. While the number of students producing different ideas and their individual response rates showed a significant difference $(p<.05)$ in three of the four teachers compared to pre-training, the number of students who answered per question showed a significant difference in only one teacher compared to pre-training. Particular attention should be paid to the individual responses of the students from these results. In the video analyzes conducted within the scope of this study, it was determined that the questions asked by the teacher were answered in three ways: First, the teacher asked the question and answered it himself, the second was the situation where the teacher asked the question and the students answered it together, and the third was when the student answered the question individually. Answering individually is important in terms of the student's construction of his own knowledge. Because, after the student has expressed his/her own opinion, the discussion and questioning of this idea by other students contributes to the better understanding of his/her own idea by reviewing it and thus its easier structuring on an individual level (Mortimer \& Scott, 2003).

In a study conducted by Helme and Clarke (2001) in support of this finding; The fact that students participate in classroom activities in this way and answer the teacher's questions individually by taking the right to speak is an indicator of their cognitive engagement. According to them, there is an important relationship between cognitive participation and learning and motivation. In other words, students' physical participation is an indication that they participate in the lesson mentally. In this respect, dialogic discourse can provide cognitive participation as well as physical participation of students. Therefore, this type of discourse has a very important place in terms of learning. This relationship between dialogic discourse and learning has the potential to be the subject of academic study in future studies.

Supporting the findings of this study, a similar study was conducted by Berekat and Mohammadi (2014) to determine the contribution of teachers' use of dialogic discourse in their classrooms to the development of students' speaking abilities. For this purpose, Berekat and Mohammadi (2014) stated 21 rules of dialogic discourse (for example, some of these rules are; allow students to ask questions, ask long-answer questions, give students the opportunity to think, enable students to listen to both the teacher and their fellow students, express their ideas without hesitation, support them, etc.). Afterwards, teachers were asked to place these rules on dialogic discourse in their classrooms. As a result of these studies, which were carried out in the form of pretest-posttest, they determined that dialogic discourse contributed significantly to the development of students' speaking abilities.

\section{CONCLUSION AND RECOMMENDATIONS}

As a result, according to the findings obtained from this study; It can be said that students will actively participate in the lesson when teachers (i) want students to explain their individual ideas and thoughts, (ii) encourage students to produce new ideas, (iii) list the ideas on the board without judgment, and (iv) use these ideas by associating them with scientific explanations over certain contexts. In future studies; It is recommended that (i) there is a significant improvement in student participation in some classes, while there is no significant improvement in other classes, and (ii) the contribution of dialogic discourse to students' academic success and scientific process skills is examined.

\section{Declaration of Conflicting Interests}

The author(s) declared no potential conflicts of interest with respect to the research, authorship, and/or publication of this article.

\section{Statements of publication ethics}

I/We hereby declare that the study has not unethical issues and that research and publication ethics have been observed carefully.

\section{Funding}

The study was supported by TUBITAK (Scientific and Technological Research Council of Turkey) (Project \#: 113K693). 


\section{Author contribution statements}

The first and second authors developed the theory and performed the computations. The third, fourth and fifth authors collected data, transcribed and analyzed. All authors discussed the results and contributed to the final manuscript.

\section{Researchers' contribution rate}

The study was conducted and reported with equal collaboration of the researchers.

\section{Ethics Committee Approval Information}

Ethics Committee Approval for the research was obtained from Gaziantep University Clinic Researches Ethics Committee with its official letter dated 11/06/2013 and numbered 223.

\section{REFERENCES}

Anderson, T., \& Shattuck, J.(2012). Design-based research: A decade of progress in education research? Educational Researcher, 41(1), 16-25. Bakhtin, M.M. (1981). The Dialogic Imagination: Four Essays. Austin.TX

Bakker A., van Eerde D. (2015). An Introduction to Design-Based Research with an Example From Statistics Education. In: Bikner-Ahsbahs A., Knipping C., \& Presmeg N. (eds). Approaches to Qualitative Research in Mathematics Education. Advances in Mathematics Education. Springer.

Berakat, B., \& Mohammadi, S.(2014). The contribution of the teachers' use of dialogic discourse pattern to the improvement of the students' speaking ability. Social and Behavioral Sciences, 98, $353-362$.

Billett, S. (1998). Appropriation and ontogeny: identifying compatibility between cognitive and sociocultural contributions to adult learning and development. International Journal of Lifelong Education, 17(1), 21-34.

Büyüköztürk, Ş. (2005). Sosyal bilimler için veri analizi el kitabı (5. Baskı). Pegem

Demirbağ, M.(2017). Otoriter ve diyalojik söylem tiplerinin fen bilgisi öğretmen adaylarının argüman gelişimine etkisi. Uludağ Üniversitesi Eğitim Fakültesi Dergisi, 30(1), 321-340.

Gillies, R., \& Khan, A. (2009). Promoting reasoned argumentation, problem-solving and learning during small-group work. Cambridge Journal of Education, 39,7-27.

Hajhosseiny, M. (2012). The effect of dialogic teaching on students' critical thinking disposition. Procedia-Social and Behavioral Sciences, 69, $1358-1368$.

Helme, S., \& Clarke, D. (2001). Identifying cognitive engagement in the mathematics classroom. Mathematics Education Research Journal, 13(2), 133-153.

Hiebert, J., R. Gallimore, H. Garneir, K. Bogard Givvin, H. Hollingsworth, J. Jacobs, et al. (2004). Teaching Mathematics in Seven Countries: Results from the TIMSS 1999 Video Study (NCES 200313 Revised). Washington, DC: U.S. Department of Education, National Center for Education Statistics.

Mercer, N., Dawes, L., Wegerif, R., \& Sams.C.(2004). Reasoning as a scientist: ways of helping children to use language to learn science. British Educational Research Journal, 30(3), 359-378.

Mercer, N., Dawes, L., \& Staarman, J.K. (2009). Dialogic teaching in the primary science classroom. Language and Education, 23(4), 353-369.

Mercer, N., Wegerif, R., \& Dawes, L. (1999). Children's talk and the development of reasoning in the classroom. British Educational Journal, 25(1), 95-111.

Miles, M.B. \& Huberman, A.M. (1994). Qualitative Data Analysis (2nd ed.). Sage.

Mortimer, E.F. (1998). Multivoicedness and univocality in classroom discourse: an example from theory of matter. International Journal of Science Education, 20(1), 67-82.

Mortimer, E.F., \& Scott, P. (2000). Analysing discourse in the science classroom. In Leach, J., Millar, R. \& Osborne, J. (Eds). Improving Science Education: the contribution of research. Open University Press.

Mortimer, E. F. (2005, January 19). Dialogic and authoritative discourse: A constitutive tension of science classroom. http://icar.cnrs.fr/ecole_thematique/analyse_video/documents/Dialogic_and_authoritative_discourse.pdf

Mortimer, E.F., \& Scott, P. (2003). Meaning making in secondary science classrooms. Open University Press.

Pratton, J., \& Hales, L. W. (1986). The effects of active participation on student learning. Journal of Educational Research, 79, $210-215$.

Sağlam, Y., Kanadlı, S., Karatepe, V., Göksu, P. ve Gizlenci, E.A. Dialogic Discourse in the Classroom. International Journal of Education in Mathematics, Science and Technology, 3(4), 322-335.

Scott, P.(2008). Talking a way to understanding in scence classroom. In N. Mercer \& S. Hodgkinson (Eds.), Exploring talk in school: Inspired by the work of Douglas Barnes (pp. 17-36). Sage.

Scott, P., Mortimer, E.F., \& Aguiar, O.G. (2006). The tension between authoritative and dialogic discourse: A fundamental characteristic of meaning making interactions in high school science lessons. Science Education, 90, 605- 631.

Scott, P. (1998). Teacher talk and meaning making in science classrooms: A Vygotskian analysis and review. Studies in Science Education, 32, 4580.

Vygotsky, L. S. (1930). Mind and society. Cambridge. Harvard University Press. 
Vygotsky, L. S. (1978). Mind in society: The development of higher psychological processes. Harvard University Press.

Wilson, S. M. \& Berne, J. (1999). Teacher learning and the acquisition of professional knowledge: An examination of research on contemporary professional development. Review of Research in Education, 24, 173-209.

Yıldırım, A., \& Şimşek, H.(2006). Sosyal bilimlerde nitel araştırma yöntemleri. Seçkin.

Appendix 1: Code definition table of authoritarian and dialogic discourses

Categories and Codes Code definitions

\section{Authoritarian Discourse Codes}

1.1. Promoting scientific view

\subsection{Judgement}

1.3. Inattention

\section{Dialogical Discourse Codes}

2.1. Being open to student view

2.2. Neutrality

2.3. Use
Situations where the teacher presents the scientific point of view to the students, asks the students for the scientific point of view, asks them to make explanations with the scientific point of view, the teacher guides the students by giving clues to find the scientific point of view, asks the students for the answers they expect, or asks for their approval,

Situations where the teacher compares the answers of the students with the scientific understanding and judges these understandings as right or wrong, and makes corrections or additions to these understandings,

Situations where the teacher neglects or ignores the answers of the students who are out of scientific understanding,

Situations where the teacher asks students for their individual opinions, asks them to explain their thoughts, asks for alternative ideas, lists these ideas on the board, through a certain context,

Situations where the teacher listens, repeats and does not judge student responses,

Situations where the teacher uses student ideas or relates them to scientific explanation. 


\begin{tabular}{|c|c|c|c|c|c|c|c|c|c|c|c|c|c|}
\hline 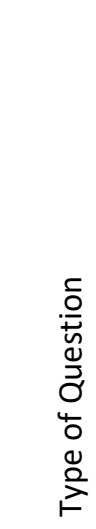 & 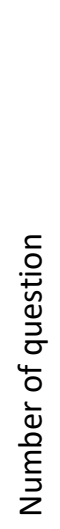 & 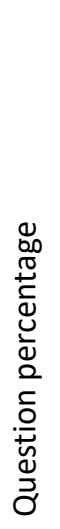 & 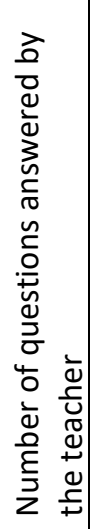 & 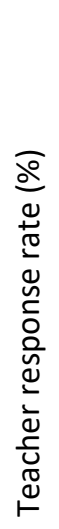 & 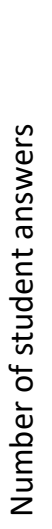 & 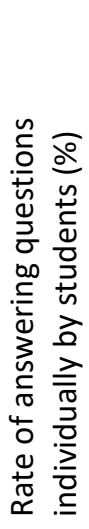 & 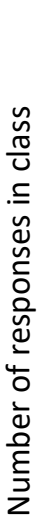 & 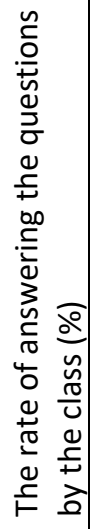 & 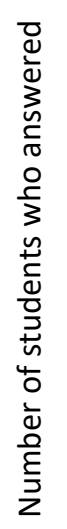 & 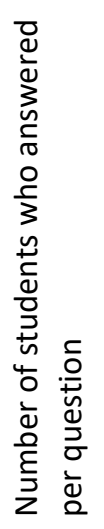 & 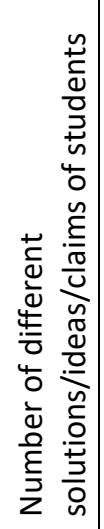 & 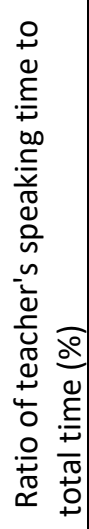 & 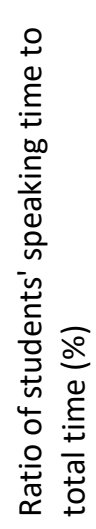 \\
\hline \multicolumn{14}{|c|}{ Confirmation } \\
\hline \multicolumn{14}{|c|}{ Selection } \\
\hline \multicolumn{14}{|c|}{ Describing } \\
\hline \multicolumn{14}{|c|}{ Explanation } \\
\hline \multicolumn{14}{|c|}{ Observation } \\
\hline Total & & & & & & & & & & & & & \\
\hline
\end{tabular}

